\title{
FACTORS ASSOCIATED WITH THE INCIDENCE OF MEASLES IN TIMOR TENGAH SELATAN DISTRICT, NUSA TENGGARA TIMUR
}

\author{
Apris Lemo Isu, Pius Weraman, Intje Picauly \\ Faculty of Public Health, Cendana University, Kupang
}

\begin{abstract}
BACKGROUND: Immunization coverage is only one of the determinants of measles incidence. High immunization is not a guaranty to avoid an extraordinary incidence of measles. This study aimed to determine factors associated with the incidence of measles in Timor Tengah Selatan district, Nusa Tenggara Timur.

SUBJECT AND METHODS: This was a case control study conducted in Kualin community health center, Timor Tengah Selatan district, Nusa Tenggara Timur. 102 cases of measles were compared with 102 controls. The independent variables included age, sex, nutritional status, access to vitamin A, immunization status, house crowdedness, presence of contact, education, family income, house ventilation, and house light. The dependent variable was measles case. Odds Ratio (OR) and chi square statistic were used to show bivariate association and statistical significance.

RESULTS: Poor nutritional status $(\mathrm{OR}=29.79$; $\mathrm{p}<0.001)$, no access to vitamin A program (OR=39.36; $\mathrm{p}<0.001)$, no immunization $(\mathrm{OR}=159.46$; $\mathrm{p}<0.001)$, crowded house $(\mathrm{OR}=18.62 ; \mathrm{p}<0.001)$, and presence of contact $(\mathrm{OR}=9.78 ; \mathrm{p}<0.001)$ were found to be risk factors of measles. Age $\geq 15$ years old $(\mathrm{OR}=0.09 ; \mathrm{p}=0.010)$ and higher family income $(\mathrm{OR}=0.03$; $\mathrm{p}<0.001)$ were found to be protective factors of measles. The association between sex $(O R=1.26 ; p=0.484)$, education $(O R=0.83 ; p=0.732)$, existence of house ventilation $(\mathrm{OR}=0.77 ; \mathrm{p}=0.597)$, house light $(\mathrm{OR}=0.88$; $\mathrm{p}=\mathrm{0.860}$ ), and the risk of measles was not statistically significant.

CONCLUTION: Poor nutritional status, no access to vitamin A program, no immunization, crowded house, and presence of contact, are risk factors of measles. Age $\geq 15$ years old and higher family income are protective factors of measles.
\end{abstract}

Keywords: measles, risk factors 